\title{
TRUTH OR CONSEQUENCES
}

\section{A. M. HARRADENCE*}

The continually increasing significance attached to "confessions" by those charged with the duties of criminal investigation and prosecution warrants a most careful scrutiny of the law relating to the admissibility of these "confessions."

It is not my intention to deal with all facets of the law on this fascinating subject but rather to deal with one vital phase upon which there is open conflict in the judicial ranics.

While the law governing the admission of confessions is by no means settled, the one fundamental requirement of all jurisdictions in Canada and England is that the confessions be "voluntary" in the manner described by Lord Sumner in the now famous decision of Ibrahim v. The King: ${ }^{1}$

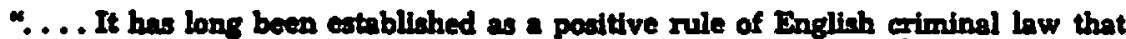
no statement by an aceused is admisable in evidence against him uniess it is chown by the prosecution to heve been a voluntary statement, in the sense that it has not been obtained from him elther by fear or prejudice or hope of advantage execrelaed or held out by a person in authority ..."

The sole ground, according to Wigmore, ${ }^{2}$ for the exclusion of statements which are not "voluntary" is simply that they are "testimonially untrustworthy."

The Supreme Court of Alberta by the majority decision of Mr. Justice Hugh John Macdonald in Regina v. Martin adopts this reasoning.

The question which immediately springs to mind is: If it can be clearly established by extraneous evidence that the confession is true, will it be admitted regardless of the circumstances under which it was obtained?

The decision of MaRuer, C.J.H.C. in the case of Regina v. St. Lawrence is of particular significance in relation to that question. The Chief Justice after an exhaustive review of the authorities dealing with confeasions which, though not voluntary, had revealed certain facts which would tend to establigh at least a portion of the confession as being true, stated at page 391:

"... There the discovery of the fact confirms the confession-that is, where the confeaston must be taken to be true by reason of the discovery of the fact-then that part of the confecelion that is confirmed by the discovery of the fact is admisable, but turther than that no part of the confeasion is admiasible. Of all the authiorities referred to, Taylor most nearly agrees with this view of the law."

This reasoning would seem to be approved by the Court of Appeal in Ontario in the case of Regina v. Briden." Porter, C.J.O., clearly states at page 163 that statements not in the form of confessions are admissible regardless of the circumstances under which they are obtained and refers with approval to the St. Lawrence case:

"In Rez v. St. Lavorence, Makuer, CJIIC. fully examined the authorities upon the principles involved. In thit case there were a number of statements made by the acoused which wese held to be involuntary. Some parts of the statement

A. IL. Farredence, of the Alberta Bar, Calory.

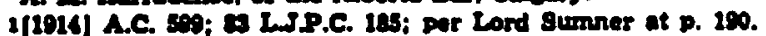

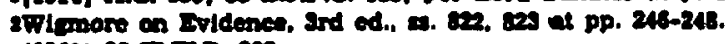

a(101) 35 F.W.R. ses.

ass C.C.C. 876.

ass C.R. 190. 
were, however, held to be admissible to show knowledge of certain material facts which were independently proven. These statements were separable from the confession.

"Where the evidence of a statement is tendered and meets with these conditions, the possbitity that it was improperly induced has no relevance. The untrustworthiness of a confession improperly induced is the main reason for its inadmissibility. Where the statement indicates knowledge of a material fect but falls short of being a confeasion, the proof of lts truth by other means removes the necessity for onquiry into its voluntariness. Unless a confession wore involved, and inseparable from such a statement, I do not think that a voir dire would be necessary to determine admissibility. No such authority was cited to us to the contrary."

Does it not follow then that if the entire confession were established to be true "by other means" that it would be admissible perhaps without a voir dire?

To determine whether a confession is voluntary a voir dire must be held. If the only evidence given on the voir dire is that of police officers, which is inevitably that.no improper procedure was followed, the Court will generally find the confession voluntary and admit the same. If the accused should take the stand in an effort to establish that it was not voluntary he may be placed in a hopeless dilempan if the question is permitted, namely: Is the statement true? The conflict referred to earlier in this article arises over whether or not such a question may be asked by the prosecution. In $\boldsymbol{R}$. v. Hammondt the accused was charged with murder and at his trial the Crown sought to put his confession in evidence. On the voir dire the accused gave evidence-in-chief that the statement had been extracted from him by physical violence. The first question put to him by Counsel for the Crown was: Your case is that this statement was not made voluntarily? - Yes. Is it true? - Yes, sir. Finally the accused was asked: What you are now saying is that you were forced into saying what was true by something that was done. Is that right? - Yes, sir. So you did kill Mr. Roberts? - Tes, sir. Naturally after that the Crown asked no more questions. The statement was admitted and the accused convicted. He appealed on the sole ground that the questions put by Counsel for the Crown an the voir dire were inadmissible. Humphreys, J. gave the judgment of the Court of Criminal Appeal and stated succinctly in referring to the questions:

\footnotetext{
"In our view, it clearly was not inedminedble. If was a perfectly natural quention to put to a perion, and was rolevant to the isque of whether the story which he was telling of being attacked and til-used by the police was trut or falie.

"It may be put as it was put by Viceount Caldecote, I.C.J. in the early part of the arrument of Couneal for the Appellant, that it rurely mut be edmitalbie, and in our view is adinisolble, becnuse it went to the credit of the person who was giving evidence. If a man say, I was forced to toll the story. I was made to say this, that and the other,' it must be relevent to know whether he was made to tell the truth, or whether he was made to say a number of thinge whlch were untrue.".
}

It is apparent that the Court of Appeal held the question to be relevant and therefore admissible solely on the grounds that they went to the accused's credibility. Therefore, it follows that great importance must have been attached by the Court of Criminal Appeal to the truthfulness of the accused at the time the confession was taken.

nfotd, at p. 164.

:|1941] a AII ER. 328.

wJold, p. 221. 
The reasoning in the Hammond case was adopted by the Ontario Court of Appeal in the judgment of Laidlaw, JA., in the case of Regina v. Laplante, in which the same circumstances arose.

The only purpose of the voir dire is to ensure that no evidence, which is not voluntary and therefore testimonially untrustworthy, be admitted in evidence. If the accused takes the stand and swears that evidence which is against his interests is true then the court is no longer concerned with whether it is voluntary, for the truth is no longer in question.

It follows, seemingly irrefutably, that if truth is established then not only statements not in the form of confessions and portions of improperly induced confessions but in fact entire confessions improperly taken, will be admitted in evidence regardless of whatever methods were used to obtain the same.

If the search for truth is to be paramount and to override every other consideration in the administration of criminal justice, then a rather undesirable situation arises on both legal and moral grounds.

Consider the impossible predicament in which the Hammond decision places an accused who has given a statement to the police. If he takes the stand on a voir dire and gives evidence that after a severe beating he confessed in order to save himself from further physical abuse and that the confession he gave to the police was false, then this fact, the fact that he lied to the police, if credibility is the issue, weighs heavily against his evidence that he was physically attacked by the police.

On the other hand, if he states that being subjected to violence he confesed and that the confession is true, if credibility again is the issue, then it must surely be to his advantage in convincing the Court that he was in fact attacked by the police, as he has apparently been truthful throughout.

Therefore, it follows that a person who states that his confession is true must be considered as more credible than one who admits lying to the police and would ostensibly be in a better position of having the statement excluded on the grounds that it was involuntary. However, as previously pointed out, once truth is established the voluntariness of the statement is of no concern.

However, one ray of hope does appear in the blunt refusal of Fall, C.J.Q.B. (Saskatchewan) in the case of Rex. v. Hnedish" to follow Rex. v. Hammond and Rex. v. LaPlante. At page 688 he comes squarely to grips with the problem and states:

"Finving regard to all the Implications involved in accepting the full impact of the Hammond dedaion which can, I think, be summirized by saying that regardleas of how much physieal and mental torture or abuse has been inflicted on an accused to coerce him into telling what is true, the canfession is admitted because It is in fact true rogardless of how it was obtained. I cannot belleve that the Hemmond decirion does refleet the final judieial reasoning of the English courts. I feel that when the point comes squarely to be decided, another court will take a hard look at the whole question, including the implication above mentioned and others.

"I do not see how under the guise of 'credibility' the court can transmute what is initially an inquiry as to the 'admisalbility' of the confession into an 
inquiaition of an accused. That would be ropugnant to our accepted standards and principles of justice; it would invite and encourage brutality in the handling of persons surpected of having committed offences."

If innocent persons are not to be placed in peril and a mockery made of the dignity of the individual, the reasoning of Hall, C.J.Q.B. must be preferred over that of Humphreys, J. and Laidlaw, J.A.

Another factor which would seem to relieve against the harsh and arbitrary rule of law enunciated in the Wigmore theory was stated by Egbert, J. in the Alberta decision of Regine v. Dreher," where he states at page 344:

"... As the Court said in Regina v. Anderson, 77 C.C.C. at 295, to say that because a statement was made without fear of projudice or hope of advantage is therefore admisslble against an accused, in complete distegard of all other factors which 'a vise rule of policy' might conisider as having exercised an lmproper influence or inducement upon the free mind of the confessor, in to fetter the wide diservtion of the trial judge to exclude the statement, a disereston exerelsable in the light of all the fects and dreumstances of the cose.."

Surely our accepted standards and principles of justice preclude the admission in evidence of at least whole confessions obtained by methods which are repugnant to any humane standard of conduct in the treatment of accused persons.

And as it has ever been in the history of the English common law it is only the courage and integrity of Her Majesty's Judges which stand between some of the more barbarous aspects of the common law and the brutality of unchecked authority.

The judgment of Hall, C.J.Q.B. is indicative of that courage and integrity which must be constantly exercised if the judicial safeguards designed to protect the innocent and the dignity of the individual are not to be brushed aside as mere impediments in the search for truth.

1114 C.R. 25. 